\title{
COVID Crisis and churches moving online - will it hasten the consumerism and commercialization of religion in Protestantism? A Sociological and Theological analysis
}

Ben Geoffrey A S

Madras Christian College, Chennai 600 059, Tamil Nadu, India

Corresponding author email : bengeof@gmail.com

ORCID ID : 0000-0001-6545-6314

\begin{abstract}
A consequence of Protestantism's aversion to monopolistic religious control is the sprouting and growth of unorganized religious establishment by enterprising individuals in Protestantism. This aversion is justified within the context of a reformed understanding of anthropology in a twofold manner. Firstly, that the corruption in human nature makes power concentrations dangerous. Secondly to prevent human beings from slacking in their duty that arise due to human weaknesses, Adam Smith's idea of competitive religious markets perform better than ones where there is monopolistic control. While Protestant theology insulates us from the dangers of power concentration and slothful duty that stem from weakness in human nature, it opens us out to new problems such as consumerism, commercialization and commodification of Christianity. With the dawn of the COVID crisis and most churches and ministries being forced to move online for broadcast and connectivity, the issues of commercialization and consumerism in religion will find new avenues for manifestation. The subject of this article is to extract wisdom and strategies to deal with the same from the early church which was placed in a very similar context of commercialization and commodification of religion.
\end{abstract}




\section{Introduction}

When Martin Luther said "My conscience is captive to the Word of God and I cannot and I will not recant anything, since it is neither safe nor right to go against conscience" ${ }^{1}$ it was then a claim to private or individual authority on matters of religion and the reformation went on to see the insulation of political authority on matters concerning religion by the separation of the authority of the Church and State that followed. The economic success of the protestant states that followed was attributed by Mark Webber to the Protestant theology $y^{2,3}$. Human beings are naturally driven by self-interest that according to Don Moore et $\mathrm{al}^{4}$, self-interest is automatic, natural and viscerally compelling while our obligation to others is a more thoughtful process of deliberation over morality. However by the common psychological biases such as confirmation and self-confirming biases ${ }^{5}$, our individualism overpowers our morality. Therefore when concentrated power is entrusted in the hands of individuals by virtue of public trust to serve the common good, it endangers the common good to be defined more likely in terms of the personal good of the individuals in power. This negative view of humanity and power comes from John Calvin's view of original sin or corruption of humanity and the total depravity of humanity that ensued ${ }^{6}$. Therefore while the powers and controls of the church sanctioned state to define and control the common good are limited, according to Adam Smith's free enterprise model, individuals pursuing their personal good bring about by an invisible hand the common good of society ${ }^{7}$. Protestantism has drawn flak from Roman Catholicism many times for lack of organized singular unity and a singular head to guide all efforts to the common good or the spiritual welfare of the many. However one may point to a largely ignored chapter in the 'Wealth of Nations' concerning religious institutions. Laurence Iannaccone demonstrates by empirical data from 17 developed western countries and confirms Smith's theory that competitive religious enterprise performs better

\footnotetext{
${ }^{1}$ Bainton, Roland Herbert. Here I stand: A life of Martin Luther. Abingdon Press, 2013.

${ }^{2}$ Sheremeta, Roman M., and Vernon L. Smith. "The impact of the reformation on the economic development of Western Europe." Available at SSRN 3192660 (2017).

${ }^{3}$ Weber, Max. The Protestant work ethic and the spirit of capitalism. Allen and Unwin, 1976.

${ }^{4}$ Moore, Don A., and George Loewenstein. "Self-interest, automaticity, and the psychology of conflict of interest." Social Justice Research 17, no. 2 (2004): 189-202

${ }^{5}$ Evans, J., and R. Pohl. "Cognitive Illusions: A Handbook on Fallacies and Biases in Thinking, Judgement and Memory." (2012).

${ }^{6}$ Palmer, Edwin H. The Five Points of Calvinism: A Study Guide. Baker Books, 1996.

${ }^{7}$ Smith, Adam. The Wealth of Nations: An inquiry into the nature and causes of the Wealth of Nations. Harriman House Limited, 2010.
} 
than religious monopoly ${ }^{8}$. The Protestant reformation saw the launch of the Counter Reformation movement by the Roman Catholic $\mathrm{Church}^{9}$. The birth of evangelical revival and charismatic movements also saw the launch of the Catholic Charismatic movement ${ }^{10,11}$. Even today the Evangelical Pentecostal and Charismatic denomination remains the fastest growing denomination in Christianity ${ }^{12,13}$. While doubts can be raised regarding its success, for success cannot be merely attributed to numbers without consideration of quality, one thing remains sure is that competition in a way to protects human beings from slacking in duty in service of the common good. While Adam Smith's competitive model for religious enterprise gives some insulation from human nature that is prone to slacking in duty, it has brought forth new problems such as consumerism and commercialization of religion that also stems from the corruption in human nature. With the COVID crisis that has forced most churches to move online for broadcast and connectivity, these issues may amplify in the new avenues available online. The discussion of such issues and some scriptural solutions is the subject of this article.

\section{Being reassured of our heritage in the face of the new}

Protestant theology's aversion to organized religion and monopolizing religious control that comes by way of religion backed politics can insulate us from the problems that arise out a monopolized establishment gone wrong or the slackness of a monopolized religious establishment. Such was the case with monarchy of ancient Israel that received the polemic of the prophets at the time of the $1^{\text {st }}$ temple period as was the case Scribes and the Pharisees who were part of the Jewish religious establishment of the second temple period and received heavy criticisms from Jesus our Lord himself. While Protestant theology may insulate us from the evils of the power of the establishment gone wrong, it opens us out to many problems that come by way of enterprising individuals and consumer power. However, on the grounds of choosing which set of problems are better ones to have, one may commend the adherence to Protestant aversion to organized religion, monopolized religious control and

\footnotetext{
${ }^{8}$ Iannaccone, Laurence R. "The consequences of religious market structure: Adam Smith and the economics of religion." Rationality and society 3.2 (1991): 156-177.

${ }^{9}$ Mullett, Michael. Historical Dictionary of the Reformation and Counter-Reformation. Scarecrow Press, 2010.

${ }^{10}$ Hocken, Peter. "The impact of the charismatic movement on the Roman Catholic Church." Journal of Beliefs \& Values 25.2 (2004): 205-216.

${ }^{11}$ Maurer, Susan A. The Spirit of Enthusiasm: A History of the Catholic Charismatic Renewal, 19672000. University Press of America, 2010.

${ }^{12}$ Johnson, Todd M. "The global demographics of the Pentecostal and charismatic renewal." Society 46.6 (2009): 479-483.

${ }^{13}$ Johnson, Todd M., and Gina A. Zurlo. "World christian database." Leiden/Boston: Brill (2007).
} 
religion backed politics. On issues such as consumerism and commercialization ${ }^{14}$ that arise out of unorganized religion that is free of political control or is protected by political tolerance, one may find wisdom in dealing with them from the writings of the New Testament writers who were placed in very similar context.

\section{Taming the beast - consumer power and its dangers}

Whilst Protestant theology shuts out the dangers of the monopolizing control of a religious establishment it still has to handle the problem of consumer power, for in the absence of organized religion, consumer power becomes the most powerful establishment to shape religion according to the consumer demands and choices. Consumerism can be defined as the adoption of a transactional approach to more and more areas of life in an attempt to create, by our choices, a life that suits our own individual desires at a price we deem worth paying ${ }^{15,16}$. While consumerism cannot be inherently evil, as it is nothing more than an individual's right to free choice, however we see many negative connotation associated with consumerism in published works and some of which are listed here : Selling God (Moore 1994 ), Spiritual Marketplace (Roof 1999), Jesus in Disneyland (Lyon 2000), Investing in Miracles (Wiegele 2005), Shopping for God (Twitchell 2007). While consumerism isn't inherently evil, Vincent J. Miller in his work 'Consuming religion: Christian faith and practice' talks about how consumer desires which drive consumer choices as being antithetical to God ${ }^{17}$. According to the late Princeton theologian Benjamin Warfield ${ }^{18}$, human beings are religious beings and therefore have a natural interest in religion, however the natural religion of human beings is carnal (worldly), for the carnal mind is at enmity with the things of God according to Paul. This is the reason for the attraction of ancient Israelites toward the Canaanite deities of fertility and material abundance such as Baal and Asherah ${ }^{19,20}$.For Canaanite deities were interested in the same things as natural man, i.e. money, sex and power. For this fashioning

\footnotetext{
${ }^{14}$ Dairo, A. Olalekan. "Privatization and commercialization of Christian message." Creativity and Change in Nigerian Christianity (2010): 193-200.

${ }^{15}$ Lyon, David. Postmodernity. U of Minnesota Press, 1999.

${ }^{16}$ Lyon, David. Jesus in Disneyland: Religion in postmodern times. John Wiley \& Sons, 2013.

${ }^{17}$ Chapter 4, Desire and Kingdom of God, Miller, Vincent J., and Vincent Jude Miller. Consuming religion: Christian faith and practice in a consumer culture. Bloomsbury Publishing USA, 2005.

${ }^{18}$ Warfield, Benjamin B. Mysticism and Christianity. CrossReach Publications via PublishDrive, 2018.

${ }^{19}$ Slater, Mariam K. "Mythologies of the Ancient World. Samuel Noah Kramer." American Anthropologist 65.6 (1963): 1380-1381.

${ }^{20}$ Van der Toorn, Karel, Bob Becking, and Pieter Willem Van Der Horst. Dictionary of Deities and Demons in the Bible. Wm. B. Eerdmans Publishing, 1999.
} 
of gods by natural man and their worship is prohibited in Mosaic Law (Lev 19:4.) For the interest of God's law given through Moses (Deut. 5:33) was meant to direct human action to a wholesome flourishing and wellness, a temporal and worldly flourishing which cannot be secured without the pursuit of a spiritual and an eternal flourishing with God Himself being the chief good and ends toward which human action is to be directed.

In the modern religious market, while accessing the success of the megachurches through published literature, the success formula of the megachurches is to package religion as a consumer or spiritual product that can be bought to solve life-debilitating material issues $^{21,22,23,24,25,26}$. To understand the popularity of this success formula from a protestant theological framework one can again turn to reformed anthropology ${ }^{27}$ and John Calvin's understanding of human nature and natural $\operatorname{man}^{28}$. The natural man in his natural state is opposed to the things of God, his natural desires are carnal and therefore his natural religion is carnal and opposed to God. Therefore by targeting a large consumer group that is worldly by packaging religion as market product that appeal to the worldly, enterprising individuals may earn success in a competitive religious market. However the consequences of such a gain is pointed out by Paul Washer a reformed pastor who warns that this formula of using carnal means to draw carnal people into the church is dangerous as more carnal means must be used to keep them and it makes the church worldly ${ }^{29}$.

\footnotetext{
${ }^{21}$ Chong, Terence. "Of riches and faith: The prosperity gospels of megachurches in Singapore." In New religiosities, modern capitalism, and moral complexities in Southeast Asia, pp. 147-168. Palgrave Macmillan, Singapore, 2017.

${ }^{22}$ Chin, Joy Tong Kooi. "McDonaldization and the megachurches: A case study of City Harvest Church, Singapore." In Religious Commodifications in Asia, pp. 200-218. Routledge, 2007.

${ }^{23}$ Benyah, Francis. "Commodification of the gospel and the socio-economics of neoPentecostal/Charismatic Christianity in Ghana." Legon Journal of the Humanities 29, no. 2 (2018): 116-145.

${ }^{24}$ Thomas, Pradip. "Selling God/saving souls: Religious commodities, spiritual markets and the media." Global Media and Communication 5, no. 1 (2009): 57-76.

${ }^{25}$ Warf, Barney, and Morton Winsberg. "Geographies of megachurches in the United States." Journal of Cultural Geography 27, no. 1 (2010): 33-51.

${ }^{26}$ Bowler, Kate. Blessed: A history of the American prosperity gospel. Oxford University Press, 2018.

${ }^{27}$ Bavinck, Herman, John Bolt, and John Vriend. Reformed Dogmatics: sin and salvation in Christ. Vol. 3. Baker Academic, 2003.

${ }^{28}$ Partee, Charles. The Theology of John Calvin. Westminster John Knox Press, 2008.

${ }^{29}$ Washer, Paul. "If the Church Uses Carnal Means to Draw Carnal Men, It Will Be Forced to Continue and Even Grow in Carnality in Order to Keep Them.” Twitter. Twitter, January 30, 2017. https://twitter.com/paulwasher/status/826207879183159297.
} 
The Apostle Paul was placed in similar Greco-Roman world ${ }^{30}$ of competing religious markets and enterprising individuals trying to win the market and seems to have anticipated this situation of the growth of a worldly religion by consumer power. He warns a younger minister Timothy and says "time will come when people will not put up with sound doctrine. Instead, to suit their own desires, they will gather around them a great number of teachers to say what their itching ears want to hear (2 Tim 4:3)." Besides having a theological conviction of not serving the material gods of Baal like Elijah, the Apostle Paul also had the practical advantage of economic independence by his tent making livelihood that gave him some independence from the religious market and the forces of consumerism ${ }^{31}$. A modern account of bi-vocational ministry in a published work also highlights the independence as one of the advantages of bi-vocational ministry ${ }^{32}$. As ministries move online, the issues of consumerism, commercialization and commodification will remain with us and will find new avenues of manifestation online but one can take wisdom from the New Testament writers who were placed in a similar context ${ }^{33}$ to address the issues of consumerism, commercialization and commodification of religion. However the modern age of information technology differs significantly from the New Testament era in this way and it is noteworthy to be highlighted. For when the New Testament writer James says that teachers will be judged more severely than others (Jam. 3:1), he speaks in age when the access to scripture was limited due to economic reasons and literacy rates that prevailed in the day. However we who live in an age of unlimited access to information because of the internet and have no such excuses unless we live in place where there is heavy Internet censorship by regulatory authorities. For in the absence of monopolizing control of religion by the state, the consumer force becomes the most powerful force and to remember the old adage, with great power comes great responsibility will serve the consumer force well.

Moreover what the competitive religious markets and free enterprise in religious would mean is, there will be winners and losers, the aggressively driven, the ambitious, the powerful will thrive into becoming megachurch leaders and the big funding for their aggressive expansion

\footnotetext{
${ }^{30}$ Jeffers, James S. The Greco-Roman world of the New Testament era: Exploring the background of early Christianity. InterVarsity Press, 2009.

${ }^{31}$ Bickers, Dennis W. The tentmaking pastor: the joy of bivocational ministry. Baker Books, 2000.

${ }^{32}$ Samushonga, Hartness M. "A theological reflection of bivocational pastoral ministry: a personal reflective account of a decade of bivocational ministry practice experience." Practical Theology 12, no. 1 (2019): 66-80.

${ }^{33}$ Jeffers, James S. The Greco-Roman world of the New Testament era: Exploring the background of early Christianity. InterVarsity Press, 2009.
} 
will eat into the smaller and the weaker will perish ${ }^{34,35}$. Whether the road to the top is driven by zeal for service or ambition is best known by the test at the top. What the popularity, fame and influence at the top means is, these people at the top are exposed to temptations of money, sex and power at a level that no other is exposed to and newspaper reports ${ }^{36,37}$ on the fall of megachurch leaders in recent times reveal that human beings only succumb to temptations common to all which are the lust of the flesh, lust of the eyes and the pride of life (1 Joh. 2:16). To address this issue, we can look at strategies and spiritual disciplines follow by people who have survived at the top with less controversy. Billy Graham the famed evangelist adopted the 'Modesto Manifesto' ${ }^{38}$ to deal with temptations of money, sex and power that come by way of being at the top ${ }^{39}$. From a protestant theological framework, one can understand this within the frame work of indwelling sin in believers as exposited by John Owen $^{40}$. The chief text for Owen's exposition comes from Paul's Letters (Rom. 7) where Paul explains about indwelling sinful nature and because of this sinful nature no one is immune from the temptations of the flesh ${ }^{41}$. Also, from the reformed theology framework, preservation of saints is only accomplished by $\operatorname{God}^{42,43}$, that though we exercise our responsibilities in working out our salvation in fear and trembling (Phil. 2:12) by keeping our spiritual disciplines, we are only able to do the right thing by the efficacious grace of God that works within us, to will the right thing and to accomplish his good purposes through them (Phil 2:13) and it is only the sovereign God who is able to keep His saints from stumbling (Jud. 1:24)

\footnotetext{
${ }^{34}$ Scotland, Nigel. "Shopping for a Church: Consumerism and the Churches." Christ and Consumerism (2000): 135.

${ }^{35}$ Thumma, Scott L., and Warren Bird. "Megafaith for the megacity: The global megachurch phenomenon." In The changing world religion map, pp. 2331-2352. Springer, Dordrecht, 2015.

${ }^{36}$ Kaufholz, Eddie, and Eddie Kaufholz. "The Mega-Problem Behind the 'Falls' of Megachurch Pastors.” RELEVANT Magazine, April 26, 2018. https://relevantmagazine.com/current16/megaproblem-behind-falls-megachurch-pastors/.

${ }^{37}$ Carlton, Genevieve. "Legendary Pastors Who Fell From Grace." Ranker. https://www.ranker.com/list/pastors-that-fell-from-grace/genevieve-carlton.

38 “The 'Modesto Manifesto': Christian History Magazine.” Christian History Institute. Accessed April 25, 2020. https://christianhistoryinstitute.org/magazine/article/the-modesto-manifesto/.

39 "'On This Date: The Modesto Manifesto - The Billy Graham Library Blog." The Billy Graham Library, October 26, 2017. https://billygrahamlibrary.org/on-this-date-the-modesto-manifesto/.

${ }^{40}$ Owen, John. Indwelling sin in believers. Gideon House Books, 2015.

${ }^{41}$ Lundgaard, Kris. The enemy within: Straight talk about the power and defeat of $\sin$. P \& R Publishing, 1998.

${ }^{42}$ MacArthur, John. "Perseverance of the Saints." The Master's Seminary Journal 4, no. 1 (1993): 524.

${ }^{43}$ Boettner, Loraine. The reformed doctrine of predestination. Pickle Partners Publishing, 2017.
} 
Finally we must be extremely cautions against the changes consumerism can bring to the relationship between members of the body of Christ ${ }^{44}$ (i.e. The Church). The Internet and globalization may rapidly continue to dissolve the distinction in many areas between the local and the global church that come by geographical bounds ${ }^{45,46}$. However the nature of relationship between the members of the body of Christ is endangered to become a consumer and service provider relationship by consumerism ${ }^{47}$, rather than being a one which is united by the Lordship of Christ made visibly manifest by primacy of the teaching and preaching of his word and our obedience to it and to be to united by the oneness that comes by partaking of His body and blood which was shed for us and being one body with many functions for the united cause of Christ in this world ${ }^{48}$.

\section{Conclusion}

Firstly in this article, we have reaffirmed the aversion of Protestant theology to monopolizing religious control and the need for free enterprise and competitive markets in religion. This is because of the dangers of power concentrations that come by way of monopolizing religious control and slacking in duty that arise if not for competition and also these dangers are found to arise because of the fallen human state as understood from a reformed anthropological framework. While Protestant theology may insulate us from the evils of the power of the establishment gone wrong, it opens us out to many problems that come by way of enterprising individuals in a competitive religious market, which are: consumerism and the commodification and commercialization of Christianity. However, on the grounds of choosing which set of problems are better ones to have, one may commend the adherence to Protestant aversion to organized religion. As ministries move online, the issues of consumerism, commercialization and commodification will remain with us and we can take wisdom from the New Testament writers who were placed in a similar context. The article highlights the wisdom of the New Testament writers in dealing with the issues of consumerism, commercialization and commodification of religion from Protestant theological frameworks

\footnotetext{
${ }^{44}$ Kuiper, Rienk Bouke. The glorious body of Christ. Eerdmans, 1958.

${ }^{45}$ Dixon, Patrick. Cyber church: Christianity and the Internet. Kingsway, 1997.

${ }^{46}$ Barna Research Group. "The Cyberchurch is coming." National survey of teenagers shows expectation of substituting Internet for corner church. Retrieved May 12 (1998): 1998.

${ }^{47}$ Bartholemew, C., and T. Moritz. "Christ and Consumerism." (2000).

${ }^{48}$ Allen, Michael, and Scott R. Swain, eds. Christian dogmatics: Reformed theology for the church catholic.

Baker Academic, 2016.
} 